\title{
Is the Rio Grande Rise a Large Igneous Province or a microcontinent?
}

\author{
J. M. O'CONNOR ${ }^{1,2 *}$, P. A. HOYER ${ }^{1}$, K. M. HAASE ${ }^{1}$, M. \\ REGELOUS $^{1}$, S. HOMRIGHAUSEN ${ }^{3}$, J. GELDMACHER ${ }^{3}$ AND \\ W. GEISSLER ${ }^{4}$ \\ ${ }^{1}$ GeoZentrum Nordbayern, Universität Erlangen-Nürnberg, \\ Erlangen, Germany \\ (*correspondence: j.m.oconnor@vu.nl) \\ ${ }^{2}$ Vrije Universiteit Amsterdam, The Netherlands \\ ${ }^{3}$ Geomar - Helmholtz-Zentrum für Ozeanforschung, Kiel, \\ Germany \\ ${ }^{4}$ Alfred Wegener Institut - Helmholtz-Zentrum für Polar- und \\ Meeresforschung, Bremerhaven, Germany
}

The Rio Grande Rise (RGR) is one of the most prominent bathymetric features in the South Atlantic Ocean. It has long been assumed that this massive oceanic plateau is a lateCretaceous Large Igenous Province related to the TristanGough mantle plume. But recent studies suggest that it might be a fragment of detached continental margin that has been preserved as a 'microcontinent' embedded in plumeinfluenced oceanic crust $[1,2]$. Here we present the first geochemical results from a combined geophysical and petrological cruise (MSM-82) carried out in spring 2019. We measured major and trace element concentrations of 47 whole rock samples dredged from the flanks of a long rift valley that cuts through the eastern (E) and western (W) parts of the RGR. Our preliminary data show that the ERGR differs in composition from the WRGR. The latter ranges from trachybasalt to trachyandesite, while the former mainly consists of alkaline basalt. Geophysical results show that the WRGR is underlain by thicker crust so the more evolved compositions might be due to longer residence times for melts in the associated magma chambers. Light rare earth element enrichment $\left[(\mathrm{La} / \mathrm{Sm})_{\mathrm{N}}: 1.5\right.$ to 6.5$]$ in all samples indicates an enriched magma source, consistent with the involvment of a mantle plume during the formation of the RGR. However, variable ratios of immobile incompatible trace elements (e.g. $\mathrm{Nb} / \mathrm{Zr}$ ) imply a heterogenous source region. All samples have high $\mathrm{Nb} / \mathrm{Th}(6.4-14.3)$ similar to oceanic basalts, indicating that they have not undergone significant contamination by a continental component with low $\mathrm{Nb} / \mathrm{Th}$. Thus, our initial findings are consistent with a plume-related magmatic origin for the RGR rather than a microcontinent.

[1] Mohriak et al., Petro. Geos. 16 (3) (2010) 231-245

[2] Santos et al., Terra Nova 31 (2019) 424-429 